\author{
Anna Dolot \\ Uniwersytet Ekonomiczny \\ w Krakowie
}

\title{
Rola procesu rekrutacji pracowników w ksztaltowaniu wizerunku przedsiębiorstw
}

\author{
The importance of recruitment process in the corporate image
}

\begin{abstract}
Streszczenie
Artykuł jest wynikiem własnych badań empirycznych autorki, prowadzonych w dużych przedsiębiorstwach na terenie miasta Krakowa. W pierwszej kolejności autorka opisała krótko, czym jest wizerunek przedsiębiorstwa, oraz wskazywała czynniki, które mogą mieć wpływ na jego kształtowanie. Następnie scharakteryzowała proces rekrutacji pracowników, oddzielając go od procesu selekcji i opisując jego funkcje oraz formy jako sposoby dotarcia do kandydatów. Znacząca część artykułu poświęcona jest prezentacji możliwych form rekrutacji wewnętrznej i zewnętrznej. Kolejną częścią artykułu są wnioski z badań empirycznych. W pierwszej kolejności autorka przedstawiła wyniki dotyczące najczęściej stosowanych form rekrutacji wewnętrznej i zewnętrznej w badanych przedsiębiorstwach. Następnie przeanalizowała wybrane elementy procesu rekrutacji oraz ich wpływ na kształtowanie wizerunku przedsiębiorstwa w oczach zatrudnionych w nim pracowników.

Artykuł opiera się również na wynikach badań wtórnych dotyczących zagadnienia dyskryminacji w ogłoszeniach o pracę.
\end{abstract}

\begin{abstract}
This article is based on the empirical research conducted in large companies in Krakow. Firstly, it defines the term of a corporate image and factors that influence it. Next, it explains the process of personnel recruitment, distinguished from the process of personnel selection, its functions and forms as the method of reaching candidates. The considerable part of the article is devoted to presenting the possible forms of internal and external recruitment. Additionally, this paper draws on the empirical research conducted by the author. Particularly, it presents the internal and external forms of recruitment employed in practice. Then, it analyses the selected elements of personnel recruitment process and its influence on a corporate image. This part of research resulted from the opinions of employees hired in the examined companies.

It is worth noting that the article also presents a secondary research concerning discrimination in job advertisements.
\end{abstract}

Słowa kluczowe: ogłoszenie o pracę; rekrutacja; rekrutacja wewnętrzna i zewnętrzna; wizerunek przedsiębiorstwa

Key words: job advertisement; recruitment; internal and external recruitment; corporate image 


\section{Wprowadzenie}

W dobie rosnącej konkurencji oraz ograniczania kosztów przedsiębiorstwa szukają nowych narzędzi, technik i metod oraz ich optymalnej kompilacji, aby wyróżnić się na rynku. Coraz większą wagę przywiązują do swojego wizerunku, coraz bardziej dostrzegają rolę pracowników w tworzeniu przewagi konkurencyjnej. Znajduje to również odzwierciedlenie w kształtowaniu wizerunku przedsiębiorstw na rynku pracy, a w odniesieniu do konkretnych działań - w prowadzeniu procesu rekrutacji oraz selekcji pracowników. Okazuje się bowiem, iż mimo raczej rosnącego bezrobocia niełatwo jest znaleźć wartościowego, kompetentnego i właściwego pracownika.

Celem niniejszej pracy jest analiza roli procesu rekrutacji w kształtowaniu wizerunku przedsiębiorstwa. Poza analizą literatury przedmiotu w obszarze istoty, rodzajów i form rekrutacji przedstawiona zostanie w niej część wyników autorskich badań empirycznych w obszarze czynników kształtujących wizerunek pracodawcy. W artykule znajdują się te dane, które bezpośrednio i pośrednio dotyczą procesu rekrutacji pracowników.

\section{Wizerunek przedsiębiorstwa i jego ksztaltowanie - charakterystyka pojęć}

Pojęcie wizerunek przedsiębiorstwa jest coraz powszechniej używane - funkcjonuje ono zarówno na rynku dóbr i usług, jak i na rynku pracy. Oznacza to, że posługują się nim klienci określonych dóbr i usług, partnerzy biznesowi poszczególnych przedsiębiorstw (np. dostawcy), a także obecni oraz potencjalni pracownicy. Istnieje wiele definicji pojęcia wizerunek przedsiębiorstwa. Dość spójnie podkreślają one istotę subiektywizmu, silne uzależnienie od ludzkich odczuć. Jedna z definicji wskazuje, iż wizerunek przedsiębiorstwa jest tym, co ludzie myślą na temat przedsiębiorstwa, stanowi subiektywne wyobrażenie o nim (Cenker, 2000). W innej definicji autor podkreśla, że wizerunek jest wypadkową określonych działań podmiotu gospodarczego oraz cech osób, do których działania te są skierowane (Gableta, 2006). W jeszcze innej definicji uwypuklono, że wizerunek stanowi zespół zarówno atrybutów racjonalnych, jak i emocjonalnych odnoszących się do danego przedsiębiorstwa. Powstają one na skutek świadomych i nieświadomych działań podmiotu gospodarczego. Jest to zatem obraz danej organizacji w świadomości społecznej, czyli to, co poszczególne jednostki o niej myślą, jak ją oceniają oraz jakie postawy wobec niej przyjmują (Urbaniak, 2003).

Choć pojawiają się w definicjach elementy związane $\mathrm{z}$ racjonalnością $\mathrm{w}$ podejściu do wizerunku przedsiębiorstwa, wydaje się, że ma on jednak w dużym stopniu charakter emocjonalny, a co z tym związane - cechuje się zmiennością w czasie, może podlegać nagłym i dynamicznym zmianom. Dodatkowo należy podkreślić, że trudnym zadaniem jest stworzenie takiego wizerunku przedsiębiorstwa, który byłby jednoznacznie pozytywnie oceniany przez całe jego otoczenie. Dzieje się tak dlatego, że poszczególne działania mogą być oceniane pozytywnie przez część odbiorców, a przez część - negatywnie. Przykładem mogą być działania przedsiębiorstw o charakterze charytatywnym. Powszechnie uznawane za pozytywne, mogą być ocenione w sposób negatywny ze względu na cel, obiekty lub osoby, którym udzielane jest wsparcie (dlaczego taki/takie a nie inny/inne). Działania mogą być negatywnie ocenione przez niektórych pracowników, którzy środki przeznaczane przez pracodawcę na pomoc innym woleliby widzieć w formie zwiększonego wynagrodzenia. Innymi słowy, tworzenie i kształtowanie wizerunku przedsiębiorstwa jest zadaniem niezwykle trudnym, wymagającym przemyślanej strategii oraz czasu.

Istnieje szeroka gama zarówno czynników, jak i strategii kształtowania i wyróżniania wizerunku przedsiębiorstwa. Jak podkreśla specjalista, można dążyć do wyróżnienia się przez optymalizację ceny produktu do jego jakości, obszar pochodzenia przedsiębiorstwa, szybkość 
obsługi, lokalizację placówek czy wyróżnienie się pracownikami. Wyróżnienie się personelem wymaga od firmy starannego doboru osób mających kontakt z klientami, a następnie dobrego ich wyszkolenia. Pracownicy (ich postawa, przejawiane zachowania, motywacja do pracy) mają szczególne znaczenie w przedsiębiorstwach świadczących usługi, gdzie kontakt z klientem ma kluczowe znaczenie (Altkorn, 2004).

Inni specjaliści (np. LeBlanc, Nguyen, 1996) wskazują, iż można wyróżnić pięć kluczowych czynników kształtowania wizerunku:

- tożsamość firmy,

- reputację,

- ofertę usługową/produktową,

- otoczenie fizyczne/środowisko,

- personel pierwszego kontaktu.

Również i w powyższej klasyfikacji wskazywana jest rola pracownika, szczególnie tego, który ma kontakt z klientem. W odniesieniu do personelu pierwszego kontaktu zwraca się uwagę na wygląd, postawę i zachowania, kompetencje.

Należy jednak podkreślić, że rola, jaką odgrywa pracownik w kształtowaniu wizerunku firmy, to nie jedynie jego sposób obsługi klienta. Tak naprawdę pracownicy kształtują wizerunek swojej firmy nie tylko w kontaktach z klientami w swoim miejscu pracy, ale również w nieformalnych, pozazawodowych sytuacjach, np. podczas spotkania z rodziną i ze znajomymi, czy podczas korzystania z usług innych firm. Można również nie być pracownikiem danej firmy i skutecznie kształtować jej wizerunek (pozytywny lub negatywny). Szczególna sytuacja ma miejsce wtedy, kiedy dana osoba ubiega się o pracę w określonym przedsiębiorstwie - bierze zatem udział w procesie rekrutacji i selekcji. Wówczas przedsiębiorstwo z jednej strony ma wobec niej określone, nierzadko wygórowane wymagania, a z drugiej strony powinno pamiętać, że kandydat może być lub stać się klientem, dostawcą czy partnerem biznesowym danego przedsiębiorstwa. Dodatkowo większość kandydatów pozostanie jedynie kandydatami, ponieważ przyjęty zostanie najczęściej tylko jeden z nich (ewentualnie kilkoro). Pozostali będą kształtować swoje wyobrażenie o danej firmie na podstawie sposobu przeprowadzenia procesu rekrutacji i selekcji oraz wszelkich informacji, jakie w tym czasie uzyskają. Zatem zarówno proces rekrutacji, jak i selekcji jest okazją do kształtowania wizerunku danego przedsiębiorstwa.

W niniejszym artykule zostanie skupiona uwaga jedynie na procesie rekrutacji, ponieważ nawet ta część całego procesu doboru pracowników wydaje się być wystarczająco interesującym czynnikiem do analizy w kontekście kształtowania wizerunku przedsiębiorstwa.

\section{Istota procesu rekrutacji}

Rekrutację można uznać za pierwszy etap złożonego procesu poszukiwania pracowników. Definiowana jest ona jako wstępny etap doboru kadr, mający na celu przekazanie informacji na zdefiniowany rynek pracy na temat gotowości zatrudnienia oraz wymogów i warunków zatrudnienia określonego rodzaju pracownika, a także przyciągnięcie określonej ilościowo i jakościowo grupy kandydatów, mogących ubiegać się o dane stanowisko pracy (Listwan, 2005). Inny autor (Ludwiczyński, 2006) definiuje rekrutację jako proces znajdowania i przyciągania dostatecznie dużej, dla celów selekcji, liczby kandydatów na nieobsadzone stanowiska pracy. Jej celem jest przekazanie rynkowi informacji o wolnym miejscu pracy i zachęcenie kandydatów do złożenia stosownych dokumentów aplikacyjnych. Pod pojęciem rynek można rozumieć zarówno potencjalnych kandydatów zewnętrznych, niebędących pracownikami danej organizacji (rekrutacja zewnętrzna), jak i zatrudnionych w danej organizacji pracowników (rekrutacja wewnętrzna) - jest to wówczas pewnego rodzaju forma rozwoju, która może również przyjąć 
postać awansu. Jak bowiem podaje A. Pocztowski (2003), rekrutacja powinna spełniać trzy funkcje:

- informacyjną (celem jest przedstawienie warunków pracy),

- motywacyjną (celem jest wywołanie odpowiedniego zainteresowania właściwych grup zawodowych, a przede wszystkim przyciągnięcie najlepszych kandydatów),

- wstępnej selekcji (celem jest wstępna weryfikacja dokumentów aplikacyjnych).

Oznacza to, że proces rekrutacji powinien być tak przygotowany i przeprowadzony, aby przyciągać najbardziej odpowiednich kandydatów, a zniechęcać tych, których udział w późniejszym (kolejnym) procesie selekcji będzie się wiązać dla przedsiębiorstwa ze stratą czasu i niepotrzebnymi kosztami.

Ważne jest, aby wyróżnić rodzaje rekrutacji: rekrutację wewnętrzną i rekrutację zewnętrzną. Rekrutacja wewnętrzna jest skierowana do zatrudnionych już pracowników. W jej obrębie istnieje podział na rekrutację zamkniętą, czyli skierowaną do określonego grona pracowników, i otwartą, czyli skierowaną do wszystkich pracowników. Rekrutacja zewnętrzna polega natomiast na przyciąganiu osób, które nie są zatrudnione w danej firmie.

Istotnym pojęciem w ramach procesu rekrutacji jest jej forma, czyli możliwe sposoby dotarcia do kandydatów. Można je podzielić w zależności od wcześniej wyróżnionej rekrutacji wewnętrznej i zewnętrznej. W przypadku rekrutacji wewnętrznej będą to np.:

- wykorzystanie własnych baz dokumentów aplikacyjnych (z wcześniejszych rekrutacji lub przez samodzielne zgłaszanie kandydatów zainteresowanych podjęciem pracy albo też jej zmianą),

- ogłoszenia zamieszczone w biuletynie czy wewnętrznej gazetce firmowej,

- e-rekrutacja w postaci: ogłoszeń zamieszonych w Intranecie (wewnętrznej sieci informatycznej danej firmy), ogłoszeń wysyłanych drogą mailową (mających szczególne zastosowanie w przypadku rekrutacji zamkniętej),

- ogłoszenia na tablicach ogłoszeń.

Każde przedsiębiorstwo może podjąć decyzję o braku korzystania z wewnętrznej formy rekrutacji (ze względu na brak odpowiednich pracowników na określone stanowisko) lub po wyczerpaniu możliwości, jakie daje wewnętrzna rekrutacja, zdecydować się na rekrutację zewnętrzną. Może zaistnieć również sytuacja, w której zostanie znaleziony pracownik wśród osób zatrudnionych, ale w konsekwencji trzeba będzie znaleźć innego pracownika na jego wakat.

Istnieje szeroki wachlarz form rekrutacji zewnętrznej. Można wymienić tu m.in.:

- ogłoszenia w mediach: ogłoszenia w prasie, radiu i telewizji (dwa ostatnie stosowane rzadko ze względu na wysokie koszty);

- ogłoszenie zamieszczone na firmowej stronie internetowej;

- ogłoszenia zamieszczane na portalach i wortalach internetowych;

- targi pracy;

- współpraca z urzędem pracy;

- szeroko pojęta współpraca z uczelniami wyższymi i innymi ośrodkami kształcenia (np. technikami czy szkołami zawodowymi). Współpraca ta może polegać na: organizowaniu wspomnianych już wcześniej targów pracy, ale adresowanych wyłącznie do studentów, uczniów i absolwentów danej uczelni/ośrodka, udziale w dniach otwartych danej uczelni/ośrodka, współpracy z biurami karier (zamieszczaniu ogłoszeń na ich stronach internetowych, wykorzystywaniu ich bazy mailingowej), organizowaniu tematycznych spotkań (nazywanych czasami „Akademiami”, np. „Akademia Rachunkowości firmy X”, szkoleń, kursów), organizowaniu praktyk i staży, współpracy z poszczególnymi wydziałami, a nawet katedrami uczelni; 
- współpraca z wyspecjalizowanymi firmami doradztwa personalnego, które mogą poprowadzić zarówno cały proces rekrutacji i selekcji, jak i wyłącznie proces rekrutacji;

- adexpress, czyli wysyłanie pocztą elektroniczną ogłoszenia rekrutacyjnego do wyselekcjonowanej grupy kandydatów - odpowiadającej konkretnym parametrom - z bazy zarejestrowanych użytkowników (taką usługę mogą proponować zarówno wyspecjalizowane firmy doradztwa personalnego, jak i portale internetowe);

- współpraca z władzami lokalnymi;

- poszukiwanie w gronie osób znanych osobiście i/lub przez znajomych, w gronie osób, których oni osobiście zarekomendują (rekrutacja wykorzystująca tzw. kontakty nieformalne);

- poszukiwanie w gronie osób znanych osobiście pracownikom (rekomendacje udzielane przez pracowników);

- ogłoszenia zamieszczane na fanpage'u firmy na portalu Facebook;

- samodzielne poszukiwanie kandydatów przez inicjowanie kontaktu z nimi (np. dzięki portalom GoldenLine, LinkedIn, Profeo).

Szczególne miejsce warto poświęcić dwóm obszarom dotyczącym procesu rekrutacji, a mianowicie ogłoszeniu o pracę (jako jednej z tradycyjnych i powszechniejszych form rekrutacji) oraz zagadnieniu e-rekrutacji (jako formie coraz powszechniejszej, wygodniejszej i tańszej dla obu stron procesu rekrutacji).

Wydaje się, że ogłoszenie o pracę nigdy nie straci na swojej aktualności, ponieważ o ile początkowo było zamieszczane najczęściej w prasie, o tyle obecnie może być zamieszczone zarówno na firmowej stronie internetowej, wybranych portalach internetowych, jak i w formie ulotki na targach pracy. Jak podkreślają specjaliści, ogłoszenie o pracę powinno (Armstrong, 2000):

- przyciągać uwagę - ogłoszenie musi konkurować o zainteresowanie kandydatów z innymi ofertami;

- wzbudzić i utrzymać zainteresowanie - musi w atrakcyjny i interesujący sposób przekazać informacje o stanowisku pracy, przedsiębiorstwie, warunkach i zasadach zatrudnienia, a także wymaganych kwalifikacjach;

- stymulować działania - komunikat musi być przekazany w sposób, który nie tylko przyciągnie uwagę, ale także zachęci do przeczytania całego ogłoszenia i doprowadzi do otrzymania dostatecznej liczby odpowiedzi od właściwych kandydatów.

Gdziekolwiek ogłoszenie o pracę zostanie zamieszczone, najczęściej ma do niego dostęp bardzo szerokie grono osób (ponieważ taki też najczęściej jest cel). Istotne jest zatem, aby zarówno pod względem wizualnym, jak i formalnym było ono nie tylko poprawne, ale i wyróżniające się. W sytuacji zamieszczania nazwy, logo i opisu firmy ogłoszenie jest doskonałym sposobem reklamy. Tworząc je, należy zwrócić uwagę na stylistykę, poprawność językową oraz zgodność z obowiązującymi przepisami prawa. Szczególnie chodzi tu o równe traktowanie pracowników, co dotyczy też procesu rekrutacji. I tak art. 183a, $\S 1$. Kodeksu pracy brzmi: „Pracownicy powinni być równo traktowani w zakresie nawiązania i rozwiązania stosunku pracy, warunków zatrudnienia, awansowania oraz dostępu do szkolenia w celu podnoszenia kwalifikacji zawodowych, w szczególności bez względu na płeć, wiek, niepełnosprawność, rasę, religię, narodowość, przekonania polityczne, przynależność związkową, pochodzenie etniczne, wyznanie, orientację seksualną, a także bez względu na zatrudnienie na czas określony lub nieokreślony albo w pełnym lub niepełnym wymiarze czasu pracy”. Dotyczy to również ogłoszeń o pracę. Tymczasem wyczerpującą analizę 60727 polskich ogłoszeń o pracę przeprowadził zespół prawników i prawniczek, a także wolontariuszek Polskiego Towarzystwa Prawa Antydyskryminacyjnego. W okresie od 1 kwietnia do 31 lipca 2009 r. badali oni, czy ogłoszenia 
w wybranych czasopismach i specjalistycznych portalach internetowych są sformułowane w sposób nienaruszający zasady równości i nieprowadzący do żadnych form dyskryminacji. W przypadku 24628 ogłoszeń stwierdzono nieprawidłowości, które mogły prowadzić do naruszenia zasady równego traktowania w zatrudnianiu. Wyniki badań z uwzględnieniem liczby ogłoszeń i przesłanek dyskryminacji przedstawia rycina 1.

Ryc. 1. Wykaz liczbowy dyskryminujących ogłoszeń o pracę z uwagi na wybrane przesłanki

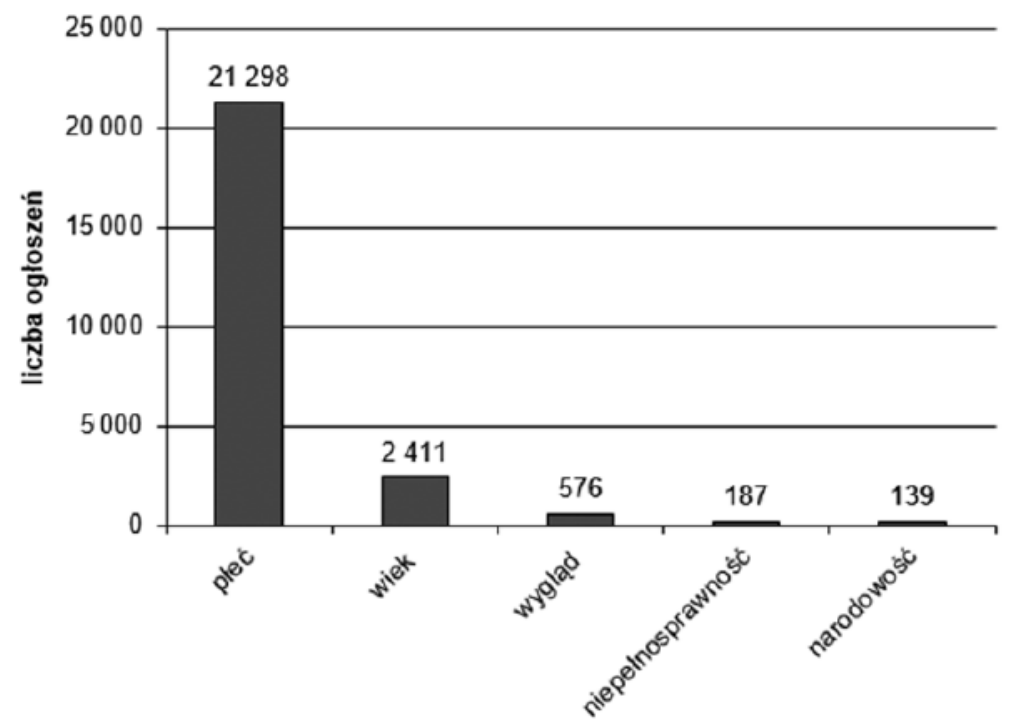

Źródło: opracowanie własne na podstawie: Kędzior, Śmiszek, Zima (2009).

Analizując dane z raportu, można stwierdzić, że w ponad 1/3 ogłoszeń widoczne są przejawy dyskryminacji, a płeć jest głównym jej obszarem. Ponieważ równouprawnienie zawodowe jest zagadnieniem podnoszonym coraz częściej, tworzenie i zamieszczanie ogłoszeń naruszających tę zasadę może w znaczącym stopniu wpływać niekorzystnie na kształtowanie wizerunku przedsiębiorstwa (szczególnie w oczach dyskryminowanych stron). Dodatkowo należy pamiętać, że ogłoszenie o pracę jest pierwszym źródłem informacji o potencjalnym stanowisku i miejscu pracy. Jego niewłaściwe przygotowanie (zamieszczenie zbyt ogólnych lub przekoloryzowanych warunków pracy) może wprowadzić kandydata w błąd. To z kolei może skutkować: po pierwsze, zgłoszeniem się niewłaściwych osób, po drugie - zwolnieniem się pracownika, rozczarowanego innymi warunkami i zasadami pracy.

Kolejnym zagadnieniem związanym z rekrutacją, któremu warto poświęcić uwagę, jest wykorzystanie Internetu. Nie można tu ominąć pojęcia e-rekrutacja, które rozumiane jest jako forma rekrutacji cechująca się m.in.: nieograniczoną lokalizacją, stosunkowo niskim kosztem jednostkowym, dużą elastycznością oraz aktualizacją on-line zebranych danych (Kawka, Listwan, 2010). Przykłady e-rekrutacji zostały zawarte w wymienionych wcześniej formach rekrutacji. W tym miejscu zostaną one rozszerzone i uporządkowane.

W prowadzeniu procesu e-rekrutacji niewątpliwie pomocne są: ogólne portale z ofertami pracy (np. Jobpilot, Pracuj.pl, Jobs.pl), portale tematyczne i branżowe, portale informacyjne, portale związków i korporacji, portale lokalne (np. miast, regionów), strony WWW szkół, 
uczelni wyższych, urzędów pracy (Jakrzewski, 2006). Usługi oferowane przez portale to: dodawanie ogłoszeń, wyróżnianie oferty, mailing, korzystanie z bazy CV, preselekcja aplikacji, korzystanie z panelu administracyjnego (Jakrzewski, 2006). Należy również podkreślić, że kandydaci do pracy (szczególnie młodszego pokolenia) coraz częściej korzystają z Internetu do wyszukiwania zarówno ofert pracy, jak i informacji o potencjalnym pracodawcy.

Niewątpliwie już na tym etapie istniejący wizerunek firmy odgrywa istotną rolę. Wydaje się również, że niemal każde działanie związane z rekrutacją (szczególnie tą zewnętrzną) będzie kształtowało wizerunek danej organizacji, szczególnie na rynku pracy. Umiejętne dotarcie do właściwych źródeł rekrutacji może zaprocentować pozytywnym zjawiskiem, tzw. kometą kadrową (Listwan, 1998), które w kontekście roli procesu rekrutacji w kształtowaniu wizerunku przedsiębiorstwa wydaje się niezwykle istotne do wyjaśnienia. Zjawisko komety kadrowej polega na tym, że przyjęty pracownik, informując innych o warunkach pracy i zatrudnienia w swojej firmie, przyciąga do niej znajomych oraz inne osoby, z którymi zetknął się w życiu zawodowym i osobistym. Wówczas firma może nie podejmować żadnych działań rekrutacyjnych, aby zgromadzić wartościowe dokumenty aplikacyjne. Jest to znacząca oszczędność czasu, a nierzadko również dużych nakładów finansowych. Należy bowiem podkreślić, że proces doboru kadr (a zatem zarówno rekrutacji, jak i selekcji) jest czasochłonny, a kiedy jest realizowany przez zewnętrzne firmy specjalistyczne - również kosztowny.

\section{Wyniki wlasnych badań empirycznych}

Badania, których wyniki zostały przedstawione poniżej, prowadzone były w okresie od maja do października 2013 r. w dużych przedsiębiorstwach mających siedzibę lub oddział na terenie miasta Krakowa. Wzięło w nich udział 122 pracowników. W każdym przedsiębiorstwie w badaniach uczestniczyło minimum pięciu pracowników, a jeden z nich zajmował stanowisko kierownicze. Ponadto w badaniu uczestniczyły działy HR reprezentujace przedsiębiorstwa. Powyższe założenia miały na celu: $\mathrm{z}$ jednej strony, zwrócenie uwagi na badany temat w przedsiębiorstwach o większych możliwościach działania (w dużych przedsiębiorstwach najczęściej wykorzystywany jest szerszy wachlarz działań niż w małych, gdyż dysponują one nierzadko większymi środkami finansowymi), z drugiej strony, celem badań było też poznanie opinii pracowników z większym doświadczeniem, zarządzających podległymi pracownikami (stąd udział respondentów na stanowiskach kierowniczych).

Badania dotyczyły zróżnicowanych czynników kształtujących wizerunek przedsiębiorstwa, jednakże w niniejszym artykule skoncentrowano się wyłącznie na aspektach dotyczących procesu rekrutacji (szczególnie z perspektywy pracowników).

W pierwszej kolejności w badanych przedsiębiorstwach poddano analizie formy rekrutacji wewnętrznej i zewnętrznej. Okazało się, że 100\% przedsiębiorstw wykorzystuje zarówno rekrutację wewnętrzną, jak i zewnętrzną. W kontekście rekrutacji wewnętrznej przedsiębiorstwa najczęściej korzystają z własnych baz dokumentów aplikacyjnych (zarówno tych niewykorzystanych we wcześniejszych rekrutacjach, jak i samodzielnych zgłoszeń kandydatów). Strukturę form rekrutacji wewnętrznej przedstawiono na rycinie 2 .

W kontekście najczęściej wykorzystywanych form rekrutacji zewnętrznej w badanych przedsiębiorstwach największą popularnością cieszą się ogłoszenia umiejscawiane na portalach internetowych przeznaczonych do tego typu działalności (np. Praca.pl, Jobpilot.pl; ryc. 3). Firmy również chętnie umieszczają ogłoszenia o pracę na swoich stronach internetowych. Pewnego rodzaju znakiem czasu jest fakt, że ogłoszenia o pracę zamieszczane są również na tzw. fanpage'u danej firmy, na portalu społecznościowym Facebook. 
Ryc. 2. Formy rekrutacji wewnętrznej w badanych przedsiębiorstwach

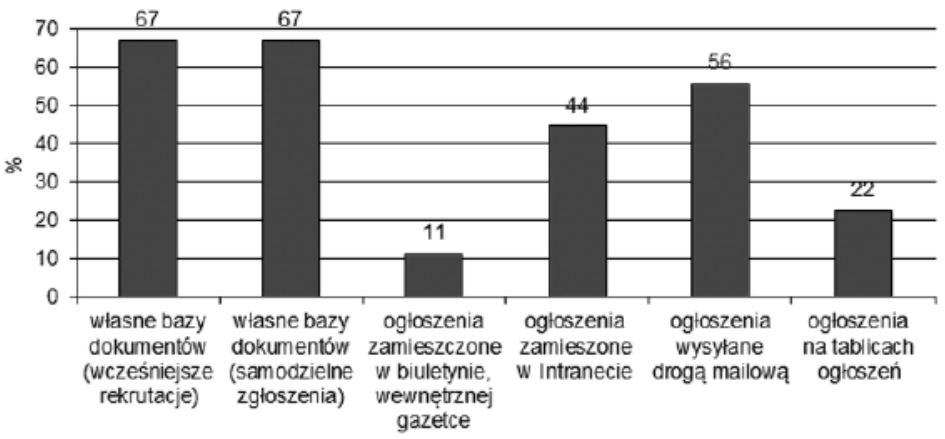

Źródło: opracowanie własne.

Ryc. 3. Formy rekrutacji zewnętrznej w badanych przedsiębiorstwach

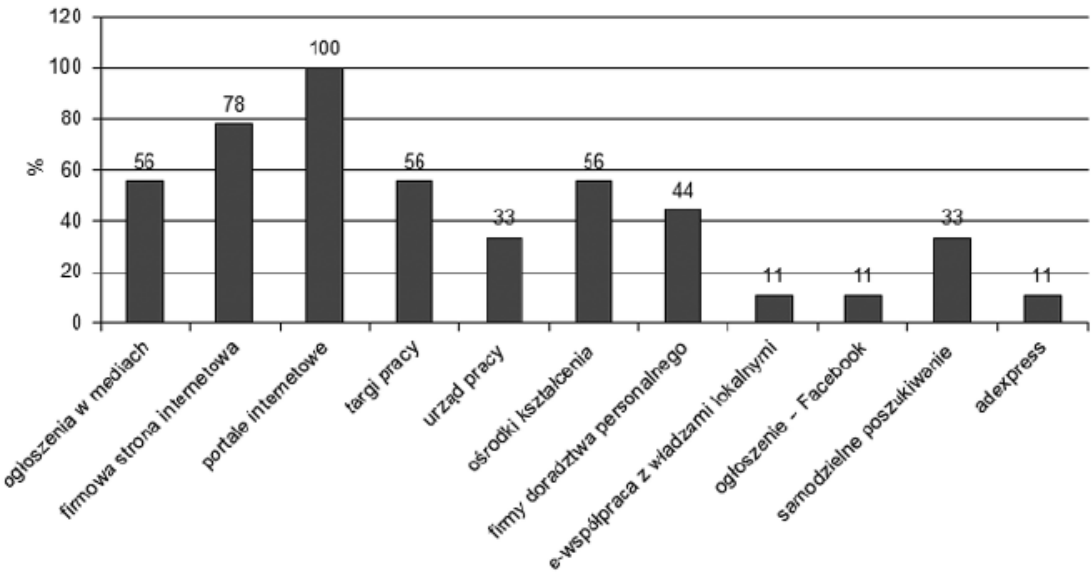

Źródło: opracowanie własne.

Warto podkreślić, że 20\% przedsiębiorstw, korzystając z pytania otwartego w kwestionariuszu, w pozycji ,inne formy rekrutacji zewnętrznej” podało własnych pracowników, którzy przekazują informacje znajomym i ich rekomendują.

W drugiej kolejności, w ramach prowadzonych badań, kwestionariusze skierowano do pracowników poszczególnych przedsiębiorstw. Należy podkreślić, że w oczach badanych respondentów cały proces doboru pracowników (a zatem i rekrutacji, i selekcji ) nie stanowi aż tak istotnego czynnika kształtowania wizerunku przedsiębiorstwa (tab. 1).

Z dziewięciu zróżnicowanych czynników zewnętrznych kształtujących wizerunek, sposób przeprowadzenia procesu rekrutacji i selekcji znalazł się na ostatnim, dziewiątym miejscu. Jednakże w opinii autorki niniejszego artykułu proces rekrutacji i selekcji jest istotnym, ponieważ angażującym emocjonalnie czynnikiem kształtowania wizerunku przedsiębiorstwa. Ze względu na to, że w zdecydowanej większości respondentami były osoby, które nie myślą o zmianie pracy, to być może ich spojrzenie na funkcję tego czynnika jest nieco inne niż spojrzenie osób, które poszukują pracy. Dodatkowo wyniki poniżej przedstawionych badań dowodzą, że poszczególne elementy procesu rekrutacji mają jednak wpływ na kształtowanie wizerunku przedsiębiorstwa. 
Tab. 1. Istotność zewnętrznych czynników kształtujących wizerunek przedsiębiorstwa w opinii badanych respondentów

\begin{tabular}{|l|c|}
\hline Firma uznawana za godną zaufania & $19,55 \%$ \\
\hline Firma, której marka jest rozpoznawalna & $17,21 \%$ \\
\hline Pozytywna opinia na rynku & $15,95 \%$ \\
\hline Pozytywna opinia znajomych & $11,44 \%$ \\
\hline Sektor, w którym działa firma & $9,95 \%$ \\
\hline Międzynarodowe środowisko pracy & $8,92 \%$ \\
\hline Firma działająca w sektorach innowacyjnych & $7,78 \%$ \\
\hline Społeczna odpowiedzialność biznesu firmy & $5,03 \%$ \\
\hline Sposób przeprowadzenia procesu rekrutacji i selekcji & $4,17 \%$ \\
\hline
\end{tabular}

Źródło: opracowanie własne.

Jak już wcześniej podkreślano, istotne znaczenie w procesie rekrutacji wydaje się mieć ogłoszenie o pracę. Spośród respondentów 37\% zdecydowanie zgadza się ze stwierdzeniem, że ogłoszenie o pracę (zamieszczone w prasie czy Internecie) kształtuje wizerunek pracodawcy (większą wagę do tego czynnika przywiązywały kobiety niż mężczyźni). Niemal 60\% zgadza się z tym twierdzeniem, a jedynie 7,5\% się z takim stwierdzeniem nie zgadza (ryc. 4). Oznacza to, że należy dołożyć wszelkich starań, aby ogłoszenie o pracę było przygotowane w sposób atrakcyjny i poprawny.

Ryc. 3. Odpowiedzi respondentów na pytanie, czy ogłoszenie o pracę (zamieszczone w Internecie, gazecie) ma wpływ na kształtowanie wizerunku przedsiębiorstwa

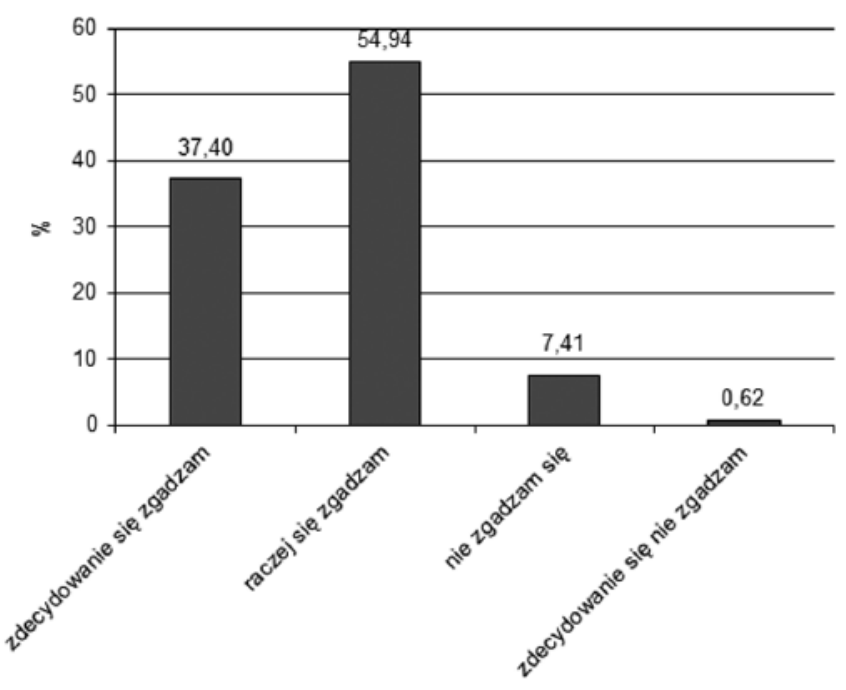

Źródło: opracowanie własne. 
Jak angażujący i ważny jest dla badanych respondentów proces rekrutacji, dowodzi odpowiedź na pytanie: „Czy poszukując nowej pracy, szukasz informacji o potencjalnym pracodawcy?". Aż 98,15\% respondentów powiedziało, że tak. Jest to bardzo cenna informacja, ponieważ wskazuje ona, że pracownicy podejmują działania, aby przygotować się do poszukiwania i zmiany pracy.

Ciekawa jest również struktura źródeł poszukiwania informacji o przedsiębiorstwie jako potencjalnym pracodawcy (ryc. 5).

Ryc. 5. Źródła poszukiwania informacji o pracodawcy w procesie rekrutacji

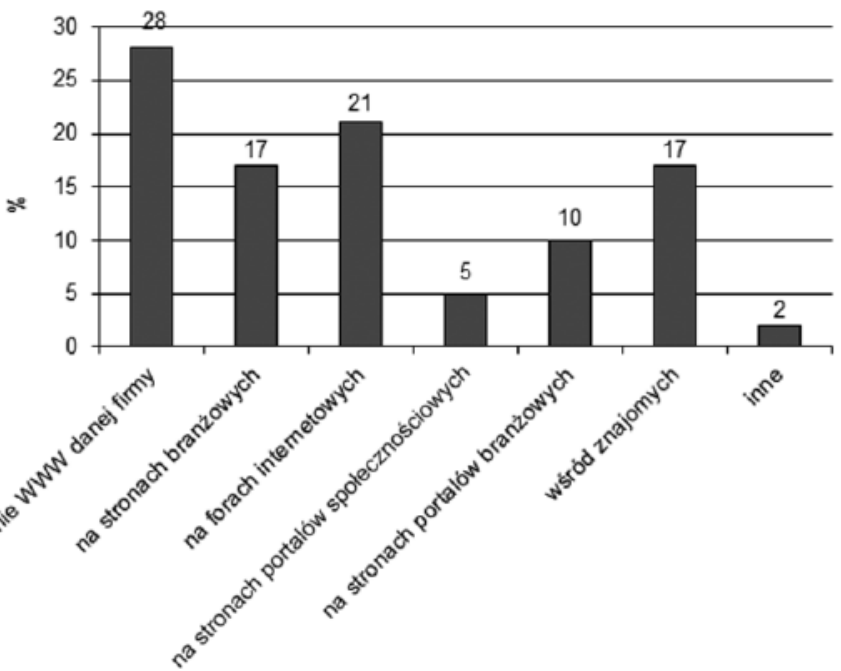

Źródło: opracowanie własne.

Bardzo podobnie odpowiadali zarówno mężczyźni, jak i kobiety. Oznacza to, że nie tylko ważne jest zamieszczanie ogłoszeń o pracę na własnej stronie firmowej, ale też dbanie o tę stronę, jej aktualizowanie czy - mówiąc ogólnie - zarządzanie nią. Ważne jest też to, że pracownicy szukają informacji o pracodawcy na forach internetowych. Trudno to źródło informacji uznać za narzędzie rekrutacji (fora internetowe powinny mieć charakter obiektywny), jednakże dla każdego przedsiębiorstwa powinien to być sygnał, że o jego wizerunku jako pracodawcy, zaletach i wadach pracy kandydaci pozyskują informacje i wypowiadają się również w Internecie. Oznacza to, że dostęp do takich wiadomości może mieć niemal każdy i na ogół zostają one zapisane na długo lub nawet na zawsze.

W literaturze przedmiotu można znaleźć informacje, iż to ci pracownicy, którzy mają bezpośredni kontakt z klientem, są czynnikiem kształtowania wizerunku przedsiębiorstwa. Z badań wynika jednak, że kandydaci szukają informacji o potencjalnym pracodawcy również u swoich znajomych. Znajomi jako pracownicy nie muszą mieć żadnego kontaktu z klientem, mogą zaś pozytywnie lub negatywnie wypowiadać się o swoim pracodawcy i w ten sposób kształtować wizerunek przedsiębiorstwa na rynku dóbr i usług, a także na rynku pracy. W pierwszym przypadku będzie to wpływało na decyzje zakupowe, w drugim - na decyzje dotyczące poszukiwania i zmiany pracy.

Choć w dzisiejszych czasach finansowy aspekt pracy ma ogromne znaczenie, to jednak respondenci wskazali warunki pracy jako najbardziej poszukiwane informacje o potencjalnym pracodawcy (ryc. 6). 
Ryc. 6. Odpowiedzi na pytanie, jakie informacje są ważne dla pracowników na temat potencjalnego pracodawcy podczas poszukiwania pracy

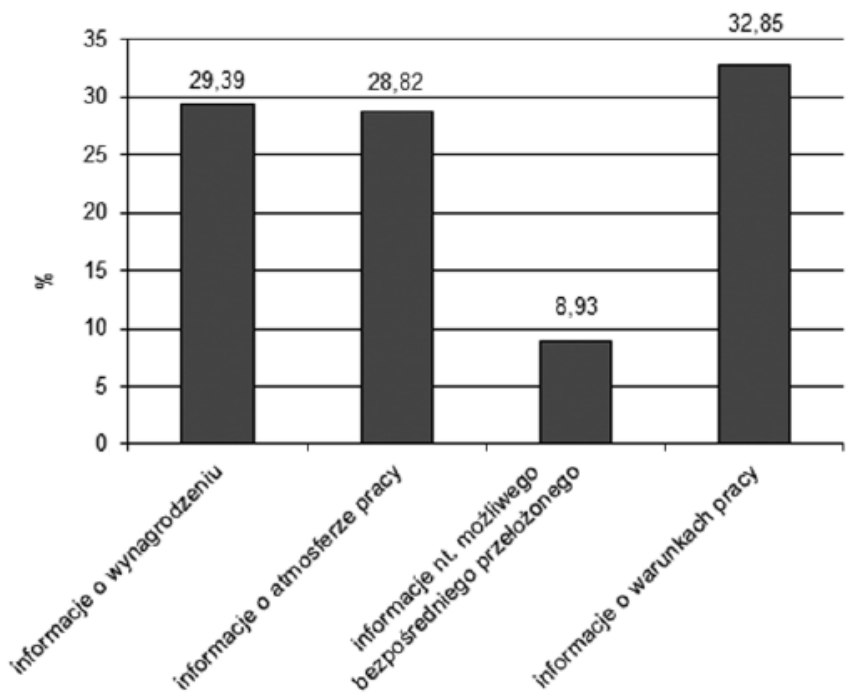

Źródło: opracowanie własne.

Co ciekawe, informacji o przyszłym bezpośrednim przełożonym najchętniej szukają pracownicy najstarsi wiekiem (powyżej 40 roku).

Najważniejszy wniosek płynący z dotychczasowych rozważań jest taki, że to, jakie informacje potencjalny kandydat pozyska o przedsiębiorstwie, może zadecydować o tym, czy złoży swoją aplikację w procesie rekrutacji, czy raczej nie. W obecnej sytuacji niepewności zdecydowana większość kandydatów przygotowuje się i aktywnie pozyskuje informacje o przedsiębiorstwie jako pracodawcy, a informacje te kształtują wizerunek przedsiębiorstwa w jego oczach. Każdemu przedsiębiorstwu powinno zatem zależeć na przyciągnięciu najlepszych kandydatów, aby dzięki temu w procesie selekcji wybrać najcenniejszych z nich.

\section{Zakończenie}

Proces rekrutacji powinien służyć pozyskaniu odpowiedniej liczby aplikacji od najlepszych kandydatów. Jak dowodzą badania empiryczne, zdecydowana większość kandydatów poszukuje informacji o potencjalnym pracodawcy. Należy mieć na uwadze, że niemal wszystkie informacje wysyłane na rynek przez przedsiębiorstwo (jak i jego pracowników, w tym te o charakterze nieformalnym) mają wpływ na kształtowanie jego wizerunku. Dzieje się tak również w kontekście przedsiębiorstwa na rynku pracy. Różne zatem działania (i te kierowane na rynek pracy, i te kierowane do zatrudnionych już pracowników) mogą skutkować pozytywnym lub negatywnym skojarzeniem i podjęciem działań lub ich zaniechaniem przez potencjalnych pracowników. W niepewnych warunkach ekonomicznych trudno, aby przedsiębiorstwa pozwalały sobie na sytuację, w której najlepsi kandydaci nie zainteresują się procesem rekrutacji. Dlatego samo przedsiębiorstwo musi dołożyć wszelkich starań, aby sygnały wysyłane na rynek pracy (czy to w formie ogłoszeń o pracę, czy przez aktywność w Internecie, czy przez samych pracowników) były pozytywne, zgodne z prawem i zasadami etyki. 


\section{Literatura \\ References}

Altkorn, J. (2004). Wizerunek firmy. Dąbrowa Górnicza: Wyższa Szkoła Biznesu w Dąbrowie Górniczej. Armstrong, M. (2000). Zarządzanie zasobami ludzkimi. Kraków: Oficyna Ekonomiczna.

Cenker, E.M. (2000). Public relations. Poznań: Wydawnictwo Wyższej Szkoły Bankowej.

Gableta, M. (2006). Potencjat pracy przedsiębiorstwa. Wrocław: Wydawnictwo Akademii Ekonomicznej. Jakrzewski, R. (2006). Jak rekrutować pracowników przez Internet. Gdańsk: Ośrodek Doradztwa i Doskonalenia Kadr Sp. z o.o.

Listwan, T. (1998). Kształtowanie kadry menedżerskiej firmy. Wrocław: Wydawnictwo Kadry.

Kawka, T., Listwan, T. (2010). Dobór pracowników. W: T. Listwan (red.), Zarządzanie kadrami. Warszawa: C.H. Beck.

Kędzior, K., Śmiszek, K., Zima, M. (2013, 30 września). Równe traktowanie w zatrudnieniu. Przepisy a rzeczywistość. Raport z monitoringu ogłoszeń o pracę. Pozyskano z http://www.ptpa.org.pl/public/ files/raport\%20pdf.pdf.

LeBlanc, G., Nguyen, N. (1996). Cues used by customers evaluating corporate image in service firms. International Journal of Service Industry Management, 7(2), 48.

Listwan, T. (red.). (2005). Stownik zarzadzania kadrami. Warszawa: C.H. Beck.

Ludwiczyński, A. (2006). Alokacja zasobów ludzkich organizacji. W: H. Król, A. Ludwiczyński (red.), Zarządzanie zasobami ludzkimi. Warszawa: Wydawnictwo Naukowe PWN.

Pocztowski, A. (2003). Zarzadzanie zasobami ludzkimi. Warszawa: Polskie Wydawnictwo Ekonomiczne. Urbaniak, M. (2003). Wizerunek dostawcy na rynku dóbr i usług. Łódź: Wydawnictwo Uniwersytetu Łódzkiego.

Anna Dolot, mgr, Uniwersytet Ekonomiczny w Krakowie, Katedra Zarządzania Zasobami Pracy.

Naukowe obszary zainteresowań autorki stanowią zagadnienia związane z rozwojem pracowników, ich pozyskiwaniem i ocenianiem (szczególnie przy wykorzystaniu takich metod, jak Assessment i Development Center) oraz motywowaniem. Autorka otworzyła przewód doktorski oraz prowadzi badania w obszarze wpływu coachingu na rozwój kompetencji pracowników. Jako trener biznesu ma również praktyczne doświadczenie w powyższych tematach.

Anna Dolot, MA, Cracow University of Economics, Faculty of Management.

The author specializes in the area of personnel development, recruitment and selection, as well as assessment (especially with the use of such methods as Assessment and Development Center) and motivation process. Her $\mathrm{PhD}$ thesis concerns coaching and its influence on development of competences. As a business trainer, she has a wide and practical experience in personnel recruitment, development, assessment and motivation.

Adres/Address: Uniwersytet Ekonomiczny w Krakowie

Katedra Zarządzania Zasobami Pracy

ul. Rakowicka 27

31-510 Kraków, Polska

e-mail: anna.dolot@uek.krakow.pl 